\title{
Title: Planning Estimates for the Mental Health Community Support Sector
}

\section{Running Title: MHCSS Planning Estimates}

Authors: $\quad$ Dan Siskind ${ }^{*}$, Lecturer $^{1}$, and Consultant Psychiatrist ${ }^{2}$ Meredith Harris, Senior Research Fellow ${ }^{1}$, Bill Buckingham, Director ${ }^{3}$, Jane Pirkis, Professor ${ }^{4}$, Harvey Whiteford, Kratzmann Professor ${ }^{1}$

1 Policy \& Economics Group, Queensland Centre for Mental Health Research, School of Population Health, The University of Queensland, Wacol, Qld

2 Princess Alexandra Hospital, Division of Mental Health, Woolloongabba, Qld

3 Buckingham and Associates, Melbourne

4 Centre for Health Policy, Programs and Economics, School of Population Health, University of Melbourne, Melbourne

*corresponding author

Queensland Centre for Mental Health Research

Level 3 Dawson House

The Park

Wacol QLD 4076

AUSTRALIA

dan siskind@qcmhr.uq.edu.au

mobile +61420680 250

office +61732718660

fax $\quad+61732718698$

Accepted by ANZJP: 1 March 2012 
Abstract

Objective: To describe the approach undertaken to derive planning estimates for the mental health community support sector in Queensland.

Methods: We quantified the needs for services by calculating prevalence of mental illness in Queensland and stratifying mental illness by severity. A taxonomy of services in the mental health community support sector was developed and target groups for services identified. Resource targets were set based on review of the academic and grey literature, expert opinion and consultation with the funding body.

Results: To provide adequate Supported Accommodation, 88 beds per 100,000 total population are required with 33.6 FTE per 100,000 total population of attached Personalised Support. An additional 12.7 FTE per 100,000 total population of Personalised Support is required for individuals living independently in the community. We estimated that 6.9 FTE per 100,000 total population would be required for provision of Group Support Services. We estimated a target of $1.6 \%$ of total mental health community support sector budget be allocated to Mutual Support and Self Help and $5 \%$ to Community Development.

Conclusions: The mental health community support sector is now a major provider of services for people with mental illness, and is likely to continue to grow. When compared to public sector clinical mental health services, the mental health community support sector has lacked clarity surrounding what services are provided, and the quantity of resources required to provide these services. In the absence of other planning information for the community mental health support sector, the estimates described here provide a first step to guide governments and policy makers. Further research and testing in the real world by mental health community support sector practitioners is required to increase the evidence base and refine resource targets.

\section{Key Words:}

Mental Health, Health Planning, Housing, Social Support, Self-Help Groups 


\section{Introduction}

People with severe and persistent mental illness have high rates of social isolation, impairments in daily living and decreased quality of life (Jablensky et al 2000). To improve social functioning and quality of life, clinical treatment should be provided alongside community support (Kopelowicz, \& Liberman 2003) as part of a "tripod" of services: clinical care; psychosocial support; and housing (Whiteford 1994).

In Australia clinical services are provided by the public and private mental health sectors, with the non-clinical mental health community support sector services delivered mostly, but not exclusively, by non-governmental organizations (NGOs) (Department of Health and Ageing 2007). Services provided by the mental health community support sector range from programs targeted at the individual such as living skills training and supported accommodation; group programs such as clubhouses; to broader community programs such as carer support and community mental health awareness. There is increasing evidence of the effectiveness of supported accommodation (Leff et al 2009; Lloyd-Evans et al 2009) personalised support (Siskind et al 2012) and clubhouse services (Psychiatric Services Editors 1999).

Following de-institutionalisation, clinical services were expanded, while community support services languished (Rosen 2006). The 1992 National Mental Health Policy identified the need for increased mental health community support sector services but did not require the development of planning targets for the sector. After nearly 20 years of mental health reform in Australia, these non-clinical services remain inadequately funded (Townsend et al 2006). For Australia to shift to funding arrangements which reflect services currently delivered, and to adequately resource the sector for current and future needs, planning targets need to be set (Pirkis et al 2007). In recognition of this need, the Fourth National Mental Health Plan calls for "targets for the mix and level of the full range of mental health services" 
across the clinical and community support sectors (Australian Health Ministers 2009a).

There are relatively few published example of planning estimates for the mental health community support sector, with most focusing solely on supported accommodation. The majority of estimates on supported accommodation are in government planning documents (Mental Health Commission 1998; NSW Department of Health 2001; Mental Health Branch 2008; South Australian Social Inclusion Board 2007; Department of Health and Children 2006), with the remainder in independent planning models (Boardman, \& Parsonage 2007; Andrews, \& the Tolkien II Team 2007) and the academic literature (Lesage et al 2003; Lesage et al 2008). There are relatively few planning estimates for other components of the mental health community support sector (New South Wales Department of Health 2001; Department of Health and Children 2006; Boardman, \& Parsonage 2007). The extent to which planning estimates can be generated and utilised depends on several factors including: how the services are defined; the roles and responsibilities of the various service providers involved; the comparability of output and planning units; and the clarity in description of underpinning assumptions.

The paucity of enumerated planning estimates and the variations in how the few existing estimates are developed and expressed creates barriers for jurisdictions such as Queensland in adopting sector wide planning estimates. The research presented here was part of a larger project to create planning estimates for Queensland across the broad range of services provided in the community mental health support sector. This manuscript represents the views of the authors, and does not necessarily represent the position of the Queensland Government. The scope of the work was focused on services funded by the Queensland State Government. In Australia, the Commonwealth Government funds employment and training programs. As these are not funded by the state government, they were out of scope. We have therefore not calculated planning estimates for this core service 
component. Future research is required to explore planning estimates for this service component.

\section{Materials and Methods}

We used a three step process to calculate planning estimates. These steps are consistent with principles for service development planning for the ideal scenario as described by Thornicroft and Tansella (Thornicroft, \& Tansella 1999) which involve examining: epidemiological needs; service provision; and service utilization.

Step 1: Quantifying the need for services

The first stage in planning for service provision was to identify and quantify the population requiring mental health community support services. We based our estimates on three assumptions. Firstly, that the majority of mental health community support services in Australia are targeted at working age adults. Secondly, that the mental health community support sector provides a variety of services for people with different levels of service need, and thirdly, that mental illness severity could be used as a proxy measure of level of need.

We began by deriving estimates of community prevalence of mental disorders, split by severity, among adults aged 18-65 years in Queensland for 2008. The estimated resident population of Queensland as at June 2008 was drawn from Australian Bureau of Statistics data (Australian Bureau of Statistics 2008). As there are no current estimates of the size and characteristics of the population with mental illness in Queensland, this data was extrapolated from the New South Wales Mental Health Clinical Care and Prevention (MH-CCP version 1.11) model (New South Wales Department of Health 2001). MH-CCP version 1.11 derives "best estimates" based on international epidemiological evidence combined with local data including the Australian Survey of Mental Health and Wellbeing (Andrews et al 2001). 
Severity was stratified into 3 levels - mild, moderate, and severe - based on definitional and epidemiological criteria developed by the US National Advisory Mental Health Council which takes into account diagnosis, disability and chronicity (New South Wales Department of Health 2001). The severe group were estimated to included $54 \%$ meeting criteria for schizophrenia (1.5\% of population); $39 \%$ for major depression ( $1.1 \%$ of population); $36 \%$ bipolar disorder ( $1.0 \%$ of population); $21 \%$ obsessive-compulsive disorder ( $0.6 \%$ of population); and $14 \%$ panic disorder ( $0.4 \%$ of population) (New South Wales Department of Health 2001). These conditions may be comorbid. As the majority of services are targeted at the severe group, and the level of need within this group varies, a more detailed examination of this group was required. The severe group was stratified into severe and persistent mental illness, and severe and episodic mental illness. The severe and persistent group was further stratified into three groups based on severity and needs estimates from Australia (Australian Bureau of Statistics 2004) and the UK (The Sainsbury Centre for Mental Health 1998): firstly, severe and persistent mental illness requiring long term institutional care; secondly severe and persistent illness capable of independent living in the community; and a third group, severe and persistent illness living in the community but with complex needs requiring multiple support. The severe and persistent illness with multi-agency needs group is characterized by people who have lost social or family support networks and rely extensively on multiple health and community services for assistance to maintain their lives outside of institutional care.

Step 2. Creating a framework for planning

A taxonomy of the services in scope was required to set the bounds of the mental health community support sector, and classify services into appropriate groups for deriving planning estimates. We reviewed existing taxonomies (Australian Institute of Health and Welfare 2003; Australian Institute of Health and Welfare 2008; Barton 1999; Bateman, \& Johnston 2000; Penrose-Wall, \& Bateman 2007; Victorian Government Department of Human Services 2008; Wood, \& Pennebaker 2004) and consulted with the 
funding agency (Queensland Department of Communities) over which components were in scope. We created a new taxonomy, designed to encompass all services in scope divided into the smallest practical number of components. Services included reflected policy priorities and best practice models. Each component was designed to: have a coherent set of output and planning units; and reflect the intent, function and focus (individual or group) of the services provided. Six core service components were identified:

- Psychosocial Support ((one-on-one activities ranging from low intensity support such as assistance with shopping and recreation to intensive assistance with daily living activities);

- $\quad$ Supported Accommodation (short and long term residential and housing based services with psychosocial support);

- Group Support Programs (groups that aim to improve the quality of life and psychosocial functioning);

- Mutual Support and Self Help (carer support and peer support services that assist individuals to share life experiences and developing support networks with people who have similar experiences);

- $\quad$ Employment and Training (programs designed to assist patients in returning to the workforce or gain further education); and

- Community Development (programs that operate on a societal scale, and aim to reduce stigma and raise awareness of mental health issues).

For each component, we mapped the service components to the target population. Target groups were identified through discussion with government disability and health service funding agencies and non-government service providers. We partitioned relevant population groups in terms of broad types of need for community mental health support services. Estimates of the size of target groups for each component were formulated.

Step 3. Setting Resource Targets

We evaluated the necessary parameters for making planning estimates and selected output and planning units for each component of the taxonomy. 
Output units were defined as a measure of the product being delivered in each core service component. Where possible, these were given as number of patients supported and number of contact hours or residential days. A planning unit is a measure of the number of patient service units provided per head of total population. These were given as beds or places per hundred thousand total population, or as a proportion of total community mental health support sector budget. A pragmatic approach was chosen for selecting output counting units and planning units. Output planning units were guided by two principles: areas in which most evidence existed; and ability to be converted to planning units.

Resource targets were set for each core component of the mental health community support sector. The exact approach for each component differed based on the evidence base for services, data available, and the underlying planning assumptions. A general approach to each component was to: define and quantify the target population; generate guiding assumptions; calculate output and planning units based on the available data and evidence; convert the planning units into resource targets per 100,000 population. Where possible, staffing resource targets of Full Time Equivalents (FTE) per 100,000 population were derived. Data and evidence were drawn from: state and national mental health planning documents; government program evaluation reports; independent planning models; and the published literature. Specific references used for each component are listed in the relevant results sections.

\section{Results}

\section{Quantifying the needs for services}

\section{Community Prevalence of Mental Disorders in Queensland in 2009}

A total of 496,603 adults or $17.8 \%$ of the adult population (aged 18-65) in Queensland were estimated to have experienced a mental disorder in 2009 (Table 1). This group is stratified by severity into mild ( $10.8 \%$ of the adult population), moderate $(4.2 \%)$ and severe $(2.8 \%)$. 
We estimated that approximately one third of those with severe disorders, or $0.9 \%$ of the adult population, are affected by a severe and persistent mental illness. This figure was based on estimates made of adults with "severe and enduring mental illness" in the UK (The Sainsbury Centre for Mental Health 1998).

The severe and persistent mental illness group included a subgroup with severe and persistent mental illness with complex, multi-agency needs. These people have lost their social connections and will require ongoing, comprehensive services from multiple agencies in order to maintain their lives in the community. We estimated that $0.4 \%$ of the adult population, or $44.4 \%$ of those with severe and persistent mental illness, had complex multi-agency needs. This was based on data from the Australian Survey of Disability, Ageing and Carers 2003, which estimated that approximately $0.4 \%$ of the adult population have a profound core-activity limitation that arises from their mental illness, and data from the UK that estimated a similar percentage of the adult population have severe and enduring mental illness that requires ongoing, comprehensive services (The Sainsbury Centre for Mental Health 1998; Australian Bureau of Statistics 2004). In Queensland, this was estimated to be 11,048 individuals.

\section{Target Populations}

Target groups for different service subtypes are outlined in Table 1. The majority of mental health community support sector services are targeted towards people with severe and persistent mental illness who have complex, multi-agency needs. Services targeted to this group are Supported Accommodation, Psychosocial Support and Group Support Services. People with severe and persistent mental illness who do not require multi-agency assistance are considered to have the capacity to benefit from support services that are provided by other sectors, primarily employment and education activities. Mutual Support and Self Help programs are targeted to all individuals with mental disorder, regardless of severity, as well as their families. Community Development programs are targeted to the general population, including people with mental illness. 
Table 1 about here

\section{Output and Planning Units and Resource Targets by Core Service}

\section{Component}

Planning estimates for all service components are summarized in Table 2, and additional detail regarding specific components is provided in Tables 3, 4 and 5 .

\section{Table 2 about here}

\section{Supported Accommodation}

Supported Accommodation is targeted at patients with severe and persistent mental illness with complex multi-agency needs. Planning estimates for Supported Accommodation were undertaken as part of The Queensland Plan for Mental Health 2007-2017 (Queensland Health 2008). Published and grey literature relating to planning estimates for supported accommodation was reviewed. Definitional boundary issues were addressed to allow comparison of services. Estimates were applied to the Queensland context, taking into account that some source estimates were derived from divergent international service contexts. Detailed derivation of these estimates is outlined in Harris et al (companion paper submitted to ANZJP). We estimated that 4,245 people require supported housing, constituting 1,397,126 residential days, and that a total of 88 beds per hundred thousand total population are required (Table 2). As the support element of supported accommodation is provided by support workers, we calculated FTE required per 100,000 to deliver required service with Personalised Support as discussed below. Supported Accommodation was broken down into: crisis accommodation and residential respite; residential rehabilitation ( $24 \mathrm{hr}$ staffed and less than 24 hour staffed); supported public housing; and supervised supported hostels; as supported by the literature and local best practice (Lloyd-Evans et al 2009; Leff et al 2009). 
Personalised Support is targeted at patients with severe and persistent mental illness with complex multi-agency needs. Estimates for Personalised Support are complex to derive. This is partially because they need to consider people who live in range of settings (residential setting, supported public housing, independent living arrangements etc.), and who may receive this support by different means (by on-site or visiting staff) at different levels of intensity. To better reflect this range of services, we divided Personalised Support into four levels of intensity, consistent with the literature and local best practice (Edwards et al 2008; Fisher et al 2007; Goodwin, \& Lyons 2001; Meehan et al 2011; NSW Health Department 2006; Seelig et al 2008; Victorian Government Department of Human Services 2008). A description of the intensity levels is given in the footnotes of Table 3 .

Personalised Support can be provided directly to patients living independently, or as a package of support provided with Supported Accommodation. We estimated that, across all levels of support intensity a total of 11,048 patients would require 2,431,356 supported contact hours per year. This would require 9,156 places, of which $42.6 \%$ would be tied to accommodation. We estimated that a total of 46.3 FTE per 100,000 total population would be required, with 12.7 FTE per 100,000 total population untied to accommodation and 33.6 FTE per 100,000 total population tied to accommodation. Planning estimates for Personalised Support are outlined in Table 3.

(Table 3 about here)

\section{Group Support Services}

Group Support Services are targeted to patients with severe and persistent mental illness with complex multi-agency needs. We estimated that 11,048 patients would require $1,715,205$ patient participation hours per year. This translates into 28.2 places per 100,000 total population. We calculated that 6.9 FTE per 100,000 total population would be required to staff these places. Assumptions and calculation of planning estimates are further outlined in Table 4. 
(Table 4 about here.)

\section{Mutual Support and Self Help}

Mutual Support and Self Help is targeted at mental health patients at all levels of severity of disorder (mild, moderate and severe), as well as the families and carers of patients and others involved in their care (Goldstrom et al 2006). Services within this category may receive funding from multiple sources, and may be provided by peers, volunteers or paid staff without lived experience. It is difficult to anticipate the exact mix of services, and is therefore difficult to generate planning estimates based on individuals serviced or number of contacts. As a result, output units could not be derived. A large proportion of staff in this category may be volunteers, making estimates of staffing resource targets impractical.

We identified the proportion of the mental health community support sector budget spent on Mutual Support and Self Help from three sources: Victoria; Queensland; and a national aggregated average of all Australian states. We estimated a target be set at $1.6 \%$, based on the national average. Assumptions and calculation of planning units are further outlined in Table 5.

(Table 5 about here)

\section{Community Development}

This component covers programs that operate at a societal level, and aim to reduce stigma, raise knowledge about and awareness of mental health issues and enhance the community's capacity to accommodate and support individuals with mental illness. The target population is the Queensland community, including all people living with mental illness. Output units and staffing resource targets were not feasible for this component. Planning units were calculated as percentage of the mental health community support sector budget. 
We identified the proportion of the non-government mental health services budget spent on Community Development in Queensland and across all Australian jurisdictions. We estimated that the target percentage of budget to be spent on Community Development be set at $5 \%$. This figure was based on discussions with the funding body. If other programs targeting illness prevention were included in this component the proportion of budget may need to be increased. Assumptions and calculation of planning units are further outlined in Table 5.

\section{Discussion}

The mental health community support sector is an important service provider for people living with mental illness. Compared with the public mental health sector, there has been a lack of clarity regarding services provided and resources required. This study is the first of its kind to yield a comprehensive set of planning estimates for the community mental health support sector.

\section{Summary of Findings}

We have estimated that a resource target of 53.2 FTE support workers per 100,000 total population in Queensland are required to meet service needs for Supported Accommodation, Personalised Support and Group Support Services. This does not include the additional staffing resources that would be required for Mutual Support and Self Help, Supported Employment and Community Development. To put this resource target in context, 70 FTE are required to meet staffing needs in the public ambulatory mental health sector in Queensland (Harris et al, companion paper submitted to ANZJP).

The distribution of resources within the sector depends on the target population. We have given greater priority to the needs of those with severe and persistent mental illness, as they have the highest burden of illness. Given the high prevalence of homelessness in this group (Folsom et al 2005), Supported Accommodation services have been prioritized. Almost three quarters (72.0\%) of the FTE resourced for Personalised Support will be given in conjunction with Supported Accommodation. The group with intensive support needs use almost half of the FTE resources for Personalised Support 
(46\%). These resource proportions could alter significantly if policy makers chose to focus on less severely impaired groups.

\section{Strengths and Limitations}

The planning estimates suggested here are based on an extensive review of the current planning literature, interpretation of trends in national and international planning, community consultation, expert opinion and value judgments as required. In the absence of other planning information for the community mental health support sector, they provide a first step to guide governments and policy makers.

The estimates are aligned with those previously developed by our group (Harris et al, companion paper submitted to ANZJP) for the Queensland Plan for Mental Health 2007-2017 (Queensland Health 2008). By aligning the resource targets across the public and community mental health sectors a more comprehensive and complementary approach to planning estimates can be achieved.

There are, however, a number of caveats that should be kept in mind in interpreting the estimates presented here. Firstly, there is a lack of data to guide many aspects of these estimates. However, we believe that waiting until more data become available is an excuse for failing to describe the services provided by the sector and failing to attempt estimates of the resourcing needed by the sector. We believe the sector has long been disadvantaged compared to the clinical services sector because of a failure to attempt the planning exercise undertaken in this paper.

We used a population based normative approach to generate estimates. This approach examines epidemiological data on population prevalence of disorders and combines it with existing evidence on service delivery. It has been used in the Queensland Plan for Mental Health 2007-2017 (Harris et al, companion paper submitted to ANZJP) and U.K. National Service Framework for Mental Health (Boardman, \& Parsonage 2007). We examined how other jurisdictions approach the structure and funding of the community mental 
health support sector and looked for examples of best practice. At times, even this level of information was unavailable, and expert opinion was relied upon. As a result, these estimates are imprecise and will need to be tested against new evidence, policy priorities and planning trends.

Secondly, the estimates are only provided only for adults, as this group is the main recipient of services provided by the community mental health support sector. Estimates were not made for other age groups or special needs populations such as forensic or indigenous patients. Thirdly the estimates are intended to guide planning at a state or national level, and are not intended for small populations. Fourthly, the conversion of planning targets in some service components to FTE equivalents is not intended to imply that services should be input funded on the basis of FTEs. FTEs are used only to show the indicative workforce required to reach capacity.

Despite these limitations, the planning estimates provided here are the best that can be achieved with the information available. They provide a basis upon which to build future estimates, and create an opportunity for debate around how planning in the mental health community support sector should be undertaken.

\section{Comparisons to other studies}

There are relatively few published examples of planning estimates for the community mental health support sector. Benchmarks in the published and grey literature focused on Supported Accommodation and varied from 33 to 131 beds per 100,000 total population. The estimate of 88 beds per 100,000 total population calculated in this study and Harris et al (companion paper submitted to ANZJP), were comparable with published benchmarks in another Australian state, South Australia (64 - 72 beds per 100,000 total population) (South Australian Social Inclusion Board 2007) and New Zealand (70 beds per 100,000) (Mental Health Commission 1998). Benchmarks from Tolkien II (51 beds per 100,000 total population) were not comparable as they are not inclusive of all disorders and do not include crisis accommodation and 
supported public housing (Andrews, \& the Tolkien II Team 2007).

Benchmarks from the UK (60 beds per 100,000 total population) did not include crisis accommodation and residential rehabilitation (Boardman, \& Parsonage 2007), while Quebec benchmarks (131 beds per 100,000) included services not currently provided in Queensland such as foster family beds (Lesage et al 2008; Lesage et al 2003). Comparison with published benchmarks were further hampered by variation in service definitions between jurisdictions and underestimation of benchmarks in health department planning reports where responsibility for Supported Accommodation fell to a different department.

The second Australian survey of people living with psychotic illness, 2010, reported that NGO services were well utilised, with one in three participants accessing both public mental health services and NGO services in the previous year and one in ten using NGO services only (Morgan et al 2011). Consumers valued NGO services, with $90 \%$ reporting that programs were helpful. One in three group NGO service users attended independent daily living skills programs and two in three individual NGO program users accessed emotional support services. These reported results fit broadly with our estimates of service usage.

\section{Implications for Policy}

The mental health community support sector is now a major provider of services for people with mental illness, and is likely to continue to grow. In the past 15 years, funding has increased from $2 \%$, on average of the state mental budgets in 1992 to 8.3\% in 2008 (Department of Health and Ageing 2010b; Australian Institute of Health and Welfare 2010). In New Zealand, NGO services already comprise $28 \%$ of the mental health budget (New Zealand Mental Health Commission 2006).

When compared to public sector clinical mental health services, the mental health community support sector has lacked clarity surrounding what services are provided, and the quantity of resources required to provide these services. 
This paper aims to provide estimates of resource targets to help guide the growth of this sector in an accountable way. A planning approach to the community mental health support sector creates an opportunity for the public and community systems to be harmonized. This aligns with the call by the National Mental Health Policy 2008 for a "seamless and connected care system which is patient focused and recovery oriented and where people are supported to engage with the community" (Australian Health Ministers 2009b). Harmonizing planning can avoid risks of service duplication or gaps in service, particularly for the most difficult to engage patients, create patient choice, and can improve access to appropriate and adequate community support that can avert hospitalization, ameliorate bed block and reduce relapse (Lloyd-Evans et al 2009).

\section{Future Directions}

On a national level, recent reforms to the Australian mental health system have raised questions about what is an adequate level of funding for mental health NGOs and how these resources should be allocated (Council of Australian Governments (COAG) 2006). There is a need for nationally agreed planning targets for community mental health support services. We feel that the development of a nationally endorsed taxonomy of services and associated planning targets should be a priority. National standards will allow greater transparency, and assist in ensuring that patient and community needs for recovery oriented community support services are met. This is consistent with calls in the Fourth National Mental Health Plan 2009-2014 to develop a national service planning framework for the full range of mental health services, including the clinical and mental health community support sectors (Australian Health Ministers 2009a).

Further work is required on these planning estimates. They provide a snapshot of the sector at the present time and are not intended to be definitive. These planning estimates are a first attempt, and aim to stimulate discussion and further research to increase the evidence base and refine resource targets. They need to be tested in the real world by mental health 
community support sector practitioners. As the target population and services delivered change, the underlying assumptions necessary for planning estimates for the mental health community support sector will need to be adjusted. Future planning estimates will need to be revised in step with the evolution of the mental health community support sector.

\section{Acknowledgements}

The authors would like to acknowledge the assistance of Ivan Frkovic and the Queensland Department of Communities, Community Mental Health Branch. 


\section{$\underline{\text { References }}$}

Andrews, G. \& the Tolkien II Team, 2007, Tolkien II: A needs-based, costed, stepped-care model for Mental Health Services, World Health Organization Collaborating Centre for Classification in Mental Health, Sydney.

Andrews, G., Henderson, S. \& Hall, W., 2001, Prevalence, comorbidity, disability and service utilisation, British Journal of Psychiatry, 178, pp. 145-53. Australian Bureau of Statistics, 2004, Australian Survey of Disability, Ageing and Carers 2003, Australian Bureau of Statistics, Canberra.

Australian Bureau of Statistics, 2008, Population Projections, Australia, 2006 to 2101 (ABS Cat. 3222.0), Australian Bureau of Statistics, Canberra.

Australian Health Ministers, 2009a, Fourth National Mental Health Plan 20092014, Commonwealth of Australia,.

Australian Health Ministers, 2009b, National Mental Health Policy 2008, Commonwealth of Australia, Canberra, ACT.

Australian Institute of Health and Welfare, 2003, National classifications of community services. Version 2.0. AlHW Cat. No. HWI 40, Australian Institute of Health and Welfare, Canberra, Australia.

Australian Institute of Health and Welfare, 2008, Commonwealth State/Territory Disability Agreement National Minimum Data Set collection Data Guide: Data items and definition 2008-09 Queensland Edition, Disability Services Queensland, Brisbane, Australia.

Australian Institute of Health and Welfare, 2010, Mental health services in Australia 2007-08, AlHW, Canberra.

Barton, R., 1999, Psychosocial rehabilitation services in community support systems: a review of outcomes and policy recommendations, Psychiatric services (Washington, D.C.), 50(4), pp. 525-34.

Bateman, J. \& Johnston, S., 2000, The MAP Project, Mental Health Coordinating Council and NSW Health Centre for Mental Health, Sydney. Boardman, J. \& Parsonage, M., 2007, Delivering the government's mental health policies - services, staffing and costs, The Sainsbury Centre for Mental Health, London.

Corrigan, P., Mueser, K., Bond, G., Drake, R. \& Solomon, P., 2008, Principals and Practice of Psychiatric Rehabilitation, The Guillford Press, New York.

Council of Australian Governments (COAG), 2006, National Action Plan on Mental Health 2006 - 2011. Available at:

http://www.coag.gov.au/meetings/140706/index.htm\#related.

Department of Health and Ageing, 2007, National Mental Health Report 2007: Summary of Twelve Years of Reform in Australia's Mental Health Services under the National Mental Health Strategy 1993-2005, Commonwealth of Australia,.

Department of Health and Ageing, 2010a, Day To Day Living Program, Department of Health and Ageing, Canberra, Australia.

Department of Health and Ageing, 2010b, National Mental Health Report 2010: Summary of 15 Years of reform in Australia's Mental Health Services 
under the National Mental Health Strategy 1993-2008, Commonwealth of Australia, Canberra, Australia.

Department of Health and Children, 2006, A Vision for Change: Report of the Expert Group on Mental Health Policy, Government of Ireland,.

Edwards, R., Fisher, K., Tannous, K. \& Robinson, S., 2008, Qld Dept of Housing Report, Brisbane.

Fisher, K., Muir, K., Dadich, A., Abello, D. \& Beasdale, M., 2007, Stage 1 Evaluation Report: Housing and Accommodation Support Initiative (HASI), NSW DEPARTMENT OF HEALTH, Sydney.

Folsom, D.P., Hawthorne, W., Lindamer, L., Gilmer, T., Bailey, A., Golshan, S., Garcia, P., Unützer, J., Hough, R. \& Jeste, D.V., 2005, Prevalence and risk factors for homelessness and utilization of mental health services among 10,340 patients with serious mental illness in a large public mental health system, The American journal of psychiatry, 162(2), pp. 370-6.

Goldstrom, I.D., Campbell, J., Rogers, J.A., Lambert, D.B., Blacklow, B., Henderson, M.J. \& Manderscheid, R.W., 2006, National estimates for mental health mutual support groups, self-help organizations, and consumeroperated services, Administration and policy in mental health, 33(1), pp. 92103.

Goodwin, R. \& Lyons, J.S., 2001, An emergency housing program as an alternative to inpatient treatment for persons with severe mental illness, Psychiatric services (Washington, D.C.), 52(1), pp. 92-5.

Jablensky, A., McGrath, J., Herrman, H., Castle, D., Gureje, O., Evans, M., Carr, V., Morgan, V., Korten, A. \& Harvey, C., 2000, Psychotic disorders in urban areas: an overview of the Study on Low Prevalence Disorders, The Australian and New Zealand journal of psychiatry, 34(2), pp. 221-36.

Kopelowicz, A. \& Liberman, R.P., 2003, Integrating treatment with rehabilitation for persons with major mental illnesses, Psychiatric services (Washington, D.C.), 54(11), pp. 1491-8.

Leff, H.S., Chow, C.M., Pepin, R., Conley, J., Allen, I.E. \& Seaman, C.A., 2009, Does one size fit all? What we can and can't learn from a meta-analysis of housing models for persons with mental illness, Psychiatric services (Washington, D.C.), 60(4), pp. 473-82.

Lesage, A., Groden, D., Goldner, E.M., Gelinas, D. \& Arnold, L.M., 2008, Regionalised tertiary psychiatric residential facilities, Epidemiologia $e$ psichiatria sociale, 17(1), pp. 38-46.

Lesage, A.D., Gélinas, D., Robitaille, D., Dion, E., Frezza, D. \& Morissette, R., 2003, Toward benchmarks for tertiary care for adults with severe and persistent mental disorders, Canadian journal of psychiatry. Revue canadienne de psychiatrie, 48(7), pp. 485-92.

Lloyd-Evans, B., Slade, M., Jagielska, D. \& Johnson, S., 2009, Residential alternatives to acute psychiatric hospital admission: systematic review, The British journal of psychiatry : the journal of mental science, 195(2), pp. 109-17. Meehan, T., Stedman, T., Robertson, S., Drake, S. \& King, R., 2011, Does supported accommodation improve the clinical and social outcomes for people with severe psychiatric disability? The Project 300 experience, Australian and New Zealand Journal of Psychiatry, 45(7), pp. 586-92. 
Mental Health Branch, 2008, Queensland Plan for Mental Health 2007-2017, Mental Health Branch, Queensland Health, Brisbane.

Mental Health Commission, 1998, Blueprint for Mental Health Services in New Zealand: How Things Need to Be, Mental Health Commission, Wellington.

Mental Health Council of Australia, 2006, Time for Service: Solving Australia's Mental Health Crisis, Mental Health Council of Australia, DEAKIN WEST ACT 2600.

Morgan, V.A., Waterreus, A.J., Jablensky, A.V., Mackinnon, A., McGrath, J.J., Carr, V., Bush, R., Castle, D., Cohen, M., Harvey, C., Galletly, C., Stain, H.J., Neil, A., McGorry, P., Hocking, B., Shah, S. \& Saw, S., 2011, People living with psychotic illness 2010. Report on the second Australian national survey, Communications Branch Dept of Health and Aging, Australia.

New South Wales Department of Health, 2001, Mental Health Clinical Care and Prevention Model: A Population Mental Health Model (MH-CCP Version 1.11), New South Wales Department of Health, Sydney.

New Zealand Mental Health Commission, 2006, Report on Progress 20042005 towards implementing the Blueprint for Mental Health Services in New Zealand, Mental Health Commission, Wellington, N.Z..

NSW Department of Health, 2001, Mental Health Clinical Care and Prevention Model: A Population Mental Health Model (MH-CCP Version 1.11), NSW Department of Health, Sydney, NSW.

NSW Health Department, 2006, Housing and Accommodation Support for People with Mental Health Problems and Disorders - NSW Government Action Plan, Department of Health, Sydney.

Penrose-Wall, J. \& Bateman, J., 2007, Working on Strengths ... the evidence so far. Models of assistance by mental health community organisations and evidence of their effectiveness, Mental Health Coordinating Council of NSW, Sydney.

Pirkis, J., Harris, M., Buckingham, W., Whiteford, H. \& Townsend-White, C., 2007, International planning directions for provision of mental health services, Administration and policy in mental health, 34(4), pp. 377-87.

Psychiatric Services Editors, 1999, Gold award: the Wellspring of the clubhouse model for social and vocational adjustment of persons with serious mental illness, Psychiatric services (Washington, D.C.), 50(11), pp. 1473-6. Queensland Health, 2008, The Queensland Plan for Mental Health 20072017, Queensland Government, Brisbane.

Rosen, A., 2006, The Australian experience of deinstitutionalization: interaction of Australian culture with the development and reform of its mental health services, Acta psychiatrica Scandinavica. Supplementum(429), pp. 819.

Seelig, T., Thompson, A., Foster, M., Phillips, R. \& Ramsden, D., 2008, Evaluation of the Queensland Health Homeless Initiative, University of Queensland,.

Siskind, D., Harris, M., Pirkis, J. \& Whiteford, H., 2012, Personalised support delivered by support workers for people with severe and persistent mental illness: a systematic review of patient outcomes, Epidemiology and Psychiatric Sciences, 21(01), pp. 97-110. 
South Australian Social Inclusion Board, 2007, Stepping Up: A Social Inclusion Action Plan for Mental Health Reform, South Australian Government,.

The Sainsbury Centre for Mental Health, 1998, Keys to Engagement. $A$ review of care for people with severe mental illness who are hard to engage with services, The Sainsbury Centre for Mental Health, London, UK.

Thornicroft, G. \& Tansella, M., 1999, The mental health matrix : a manual to improve services, illustrated ed. Cambridge University Press, Cambridge, UK ; New York, NY.

Townsend, C.E., Pirkis, J.E., Pham, A.T.N., Harris, M.G. \& Whiteford, H.A., 2006, Stakeholder concerns about Australia's mental health care system, Australian health review : a publication of the Australian Hospital Association, 30(2), pp. 158-63.

Victorian Government Department of Human Services, 2008, Victoria-public hospitals and mental health services Policy and funding guidelines 2008-09, State Government of Victoria, Melbourne, Victoria.

Whiteford, H. \& Buckingham, B., 2006, COAG Care Coordinators - Estimating the size of the target population: Adults with severe and persistent mental illness who have complex and multiple service needs, Prepared for Commonwealth Department of Health and Ageing, unpublished.

Whiteford, H.A., 1994, The first National Mental Health Report, The Medical journal of Australia, 161(7), pp. 438-40.

Wood, C. \& Pennebaker, D., 2004, A classification of service types and glossary of terminology for non-government mental health services, The HIM journal, 32(2), pp. 41-50. 
Table 1

Estimated adult prevalence of mental disorders by severity level, Queensland, June 2009 and aligned service components $\dagger, \ddagger, \S, \|$

\begin{tabular}{|c|c|c|c|}
\hline Severity level § & $\begin{array}{r}\text { Number of } \\
\text { Adults }\end{array}$ & $\begin{array}{r}\text { Percentage of } \\
\text { Adult Population }\end{array}$ & $\begin{array}{r}\text { Service components } \\
\text { targeted to this subset of } \\
\text { population } \dagger\end{array}$ \\
\hline Total Qld Population & $4,406,823$ & $100 \%$ & Community Development \\
\hline $\begin{array}{l}\text { Mild, Moderate or Severe } \\
\text { Mental Illness }\end{array}$ & 496,603 & $17.8 \%$ & $\begin{array}{l}\text { Mutual Support and Self } \\
\text { Help } \neq \ddagger\end{array}$ \\
\hline Mild Mental Illness & 301,310 & $10.8 \%$ & \\
\hline Moderate Mental IIIness & 117,176 & $4.2 \%$ & \\
\hline Severe Mental IIIness $\rrbracket$ & 78,117 & $2.8 \%$ & \\
\hline $\begin{array}{l}\text { Severe and persistent } \\
\text { mental illness (SPMI) }\end{array}$ & 25,109 & $0.9 \%$ & \\
\hline $\begin{array}{l}\text { SPMI with complex } \\
\text { multi-agency needs }\end{array}$ & 11,048 & $0.4 \%$ & $\begin{array}{l}\text { Personalised Support } \\
\text { Group Support Services } \\
\text { Supported Accommodation }\end{array}$ \\
\hline
\end{tabular}

Based on Harris et al (companion paper submitted to ANZJP), revised to 2009 population.

$\dagger$ Figures are one year prevalence estimates.

$\ddagger$ Estimates exclude dementia and alcohol and drug-related disorders except where these are concurrent with a mental disorder.

$\S$ Severity is determined by three factors - diagnosis, disability and duration (chronicity)

II Population data are Estimated Resident Population of Queensland adults as at June 2008 (Australian Bureau of Statistics 2008) . Estimates of the size and characteristics of the Queensland population with mental illness were derived from the New South Wales MH-CCP model (New South Wales Department of Health 2001) and the Australian Survey of Mental Health and Wellbeing (Andrews et al 2001).

I The severe group is further divided into: SPMI (33.3\% of the severe group); and SPMI with complex multi-agency needs (14.2\% of the severe group) (Australian Bureau of Statistics 2004; The Sainsbury Centre for Mental Health 1998).

†† This table provides the broad population segments that are the target of each component. Not all members of each population segment will actually receive the service

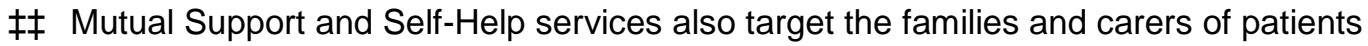
and others involved in their care. 
Table 2 Summary of Planning Estimates $\dagger, \ddagger$

\begin{tabular}{|c|c|c|c|c|c|c|}
\hline & \multicolumn{2}{|c|}{ Output units } & \multicolumn{2}{|c|}{ Planning units required } & \multicolumn{2}{|c|}{$\begin{array}{l}\text { Workforce required } \\
\text { to achieve capacity }\end{array}$} \\
\hline Service component & Output units & $\begin{array}{l}N \text { output } \\
\text { units per } \\
\text { year }\end{array}$ & Planning unit & $\begin{array}{l}\text { Per } \\
100 k\end{array}$ & $\begin{array}{l}\text { Actual } \\
\text { number } \\
\text { of FTE } \\
\text { required }\end{array}$ & $\begin{array}{l}\text { Indicative } \\
\text { FTE } \\
\text { required } \\
\text { per 100k }\end{array}$ \\
\hline \multicolumn{7}{|c|}{$\begin{array}{l}\text { Supported Accommodation } \\
\text { (FTE are the Personalised Support estimates for patients in Supported Accommodation) } \\
\text { - Crisis }\end{array}$} \\
\hline $\begin{array}{l}\text { Accommodation } \\
\text { and Residential } \\
\text { Respite }\end{array}$ & $\begin{array}{l}\mathrm{N} \text { patients }+ \\
\mathrm{N} \text { residential days }\end{array}$ & $\begin{array}{l}529 \\
41,045\end{array}$ & Beds per 100k & 3 & 155 & 3.5 \\
\hline $\begin{array}{l}\text { - Residential } \\
\text { Rehabilitation (24 hr) }\end{array}$ & $\begin{array}{l}\mathrm{N} \text { patients }+ \\
\mathrm{N} \text { residential days }\end{array}$ & $\begin{array}{l}220 \\
76,456\end{array}$ & Beds per $100 \mathrm{k}$ & 5 & 259 & 5.9 \\
\hline $\begin{array}{l}\text { - Residential } \\
\text { Rehabilitation }(<24 \\
\text { hr) }\end{array}$ & $\begin{array}{l}\mathrm{N} \text { patients }+ \\
\mathrm{N} \text { residential days }\end{array}$ & $\begin{array}{l}441 \\
152,911\end{array}$ & Beds per $100 \mathrm{k}$ & 10 & 185 & 4.2 \\
\hline $\begin{array}{l}\text { - Supported Public } \\
\text { Housing }\end{array}$ & $\begin{array}{l}\mathrm{N} \text { patients }+ \\
\mathrm{N} \text { residential days }\end{array}$ & $\begin{array}{l}1,542 \\
563,357\end{array}$ & $\begin{array}{l}\text { Supported Places } \\
\text { per } 100 \mathrm{k}\end{array}$ & 35 & 674 & 15.3 \\
\hline $\begin{array}{l}\text { - Supervised } \\
\text { Supported } \\
\text { Hostels }\end{array}$ & $\begin{array}{l}\mathrm{N} \text { patients }+ \\
\mathrm{N} \text { residential days }\end{array}$ & $\begin{array}{l}1,542 \\
563,357\end{array}$ & $\begin{array}{l}\text { Supported Places } \\
\text { per } 100 \mathrm{k}\end{array}$ & 35 & 208 & 4.7 \\
\hline Subtotal & $\begin{array}{l}\mathrm{N} \text { patients }+ \\
\mathrm{N} \text { residential days }\end{array}$ & $\begin{array}{l}4274 \\
1,397,126\end{array}$ & & 88 & 1482 & 33.6 \\
\hline \multicolumn{7}{|l|}{$\begin{array}{l}\text { Personalised } \\
\text { Support }\end{array}$} \\
\hline - High support & $\begin{array}{l}\mathrm{N} \text { patients supported } \\
\mathrm{N} \text { patient contact hours }\end{array}$ & $\begin{array}{l}1,764 \\
3,670\end{array}$ & Places per $100 \mathrm{k}$ & 8.3 & 163 & 3.7 \\
\hline - Medium support & $\begin{array}{l}\mathrm{N} \text { patients supported } \\
\mathrm{N} \text { patient contact hours }\end{array}$ & $\begin{array}{l}452 \\
2,260\end{array}$ & Places per $100 \mathrm{k}$ & 10.3 & 100 & 2.3 \\
\hline - Low support & $\begin{array}{l}\mathrm{N} \text { patients supported } \\
\mathrm{N} \text { patient contact hours }\end{array}$ & $\begin{array}{l}4,459 \\
6,689\end{array}$ & Places per $100 \mathrm{k}$ & 101.2 & 297 & 6.7 \\
\hline Subtotal & $\begin{array}{l}\mathrm{N} \text { patients supported } \\
\mathrm{N} \text { patient contact hours }\end{array}$ & $\begin{array}{l}6,675 \\
12,619\end{array}$ & & 119.8 & 561 & 12.7 \\
\hline $\begin{array}{l}\text { Group Support } \\
\text { Services }\end{array}$ & $\begin{array}{l}\mathrm{N} \text { patients }+ \\
\mathrm{N} \text { patient participation } \\
\text { hrs }\end{array}$ & $\begin{array}{l}11,048 \\
1,715,205\end{array}$ & Places per $100 \mathrm{k}$ & 28.2 & 302 & 6.9 \\
\hline $\begin{array}{l}\text { Mutual Support and } \\
\text { Self-Help }\end{array}$ & & & $\begin{array}{l}\% \text { of total mental } \\
\text { health community } \\
\text { support services } \\
\text { budget }\end{array}$ & $1.6 \%$ & - & - \\
\hline $\begin{array}{l}\text { Community } \\
\text { Development }\end{array}$ & - & - & $\begin{array}{l}\% \text { of total mental } \\
\text { health community } \\
\text { support services } \\
\text { budget }\end{array}$ & $5.0 \%$ & - & - \\
\hline
\end{tabular}

'- not estimated

Note that totals may not sum exactly, due to rounding

$\dagger$ Planning targets for Personalised Support are provided for the accommodation and non-accommodation components separately. Personalised Support for patients in Crisis Accommodation and Residential Respite beds, and Residential rehabilitation beds, is provided by on-site staff and is included under the relevant Supported Accommodation 
service components. Personalised Supported for Supported Public Housing, Supervised Supported Hostels, and the non-accommodation components is provided by visiting staff and is included under the relevant Personalised Support service components.

$\ddagger$ For the derivation of planning estimates for Supported Accommodation, we have grouped the service elements into 4 categories aligning with those described in The Queensland Plan for Mental Health 2007-2017 (Queensland Health 2008), with

Residential Rehabilitation further divided into 24 hours support and less than 24 hour support. 
Table 3 Personalised Support†‡

\begin{tabular}{|c|c|c|c|c|c|c|c|c|c|}
\hline \multirow{2}{*}{$\begin{array}{l}\text { Level of } \\
\text { support } \\
\text { intensity } \\
\S\end{array}$} & \multirow[b]{2}{*}{$\begin{array}{l}\text { Psychosocial Support } \\
\text { Indicative Activities } \\
\text { (Not tied to housing) }\end{array}$} & \multirow[b]{2}{*}{$\begin{array}{l}\text { N places } \\
\text { (\% of } \\
\text { subtotal) }\end{array}$} & \multirow{2}{*}{$\begin{array}{l}\text { Psychosocial Support Indicative } \\
\text { Activities and Supported } \\
\text { Accommodation Service } \\
\text { Components (Tied to housing) }\end{array}$} & \multirow[b]{2}{*}{$\begin{array}{c}\mathbf{N} \\
\text { places }\end{array}$} & \multirow{2}{*}{$\begin{array}{l}\text { Persons } \\
\text { per } \\
\text { place } \\
\text { per year }\end{array}$} & \multirow[b]{2}{*}{$\begin{array}{l}\text { Total } \\
\text { people }\end{array}$} & \multicolumn{3}{|c|}{$\begin{array}{c}\text { FTE per 100k required to } \\
\text { reach capability } \|\end{array}$} \\
\hline & & & & & & & $\begin{array}{c}\text { Not tied } \\
\text { to } \\
\text { housing }\end{array}$ & $\begin{array}{c}\text { Tied to } \\
\text { housing }\end{array}$ & Total \\
\hline \multirow{4}{*}{$\begin{array}{l}\text { Intensive } \\
\text { (28 } \\
\text { hours) } 9\end{array}$} & - & - & Supported public housing & 434 & 1 & 434 & & & 12.3 \\
\hline & & & $\begin{array}{l}\text { Residential Rehabilitation }(24 \mathrm{hr} \\
\text { staffed) }\end{array}$ & 220 & 1 & 220 & & & 5.9 \\
\hline & & & Crisis housing/Residential respite & 132 & 4 & 529 & & & 3.5 \\
\hline & subtotal & $0(0 \%)$ & & $\begin{array}{c}786 \\
(100 \%)\end{array}$ & & 1,183 & & 21.7 & 21.7 \\
\hline \multirow{6}{*}{$\begin{array}{l}\text { High } \\
(10 \\
\text { hours)†† }\end{array}$} & & & $\begin{array}{l}\text { Residential Rehabilitation ( }<24 \mathrm{hr} \\
\text { staffed) }\end{array}$ & 441 & 1 & 441 & & & 4.2 \\
\hline & & & $\begin{array}{l}\text { Supported public housing } \\
\text { (Transitional) }\end{array}$ & 100 & 2 & 200 & & & 1.0 \\
\hline & Early intervention & 122 & & & 6 & $732 \neq \neq$ & & & 1.2 \\
\hline & Psychosocial support & 120 & & & 1 & $122 \neq \neq$ & & & 1.2 \\
\hline & Home-based respite & 125 & & & 13 & $\begin{array}{l}910 \neq \ddagger \\
\S \S\end{array}$ & & & 1.3 \\
\hline & subtotal & $\begin{array}{c}367 \\
(40.5 \%)\end{array}$ & & $\begin{array}{c}541 \\
(59.5 \%)\end{array}$ & & 2,405 & 3.7 & 5.2 & 8.9 \\
\hline \multirow{3}{*}{$\begin{array}{l}\text { Medium } \\
(5 \\
\text { hours })||||\end{array}$} & & & $\begin{array}{l}\text { Supported public housing } \\
\text { Supported supervised hostels }\end{array}$ & $\begin{array}{l}145 \\
679\end{array}$ & $\begin{array}{l}1 \\
1\end{array}$ & $\begin{array}{l}145 \\
679\end{array}$ & & & $\begin{array}{l}0.7 \\
3.4\end{array}$ \\
\hline & $\begin{array}{l}\text { Living skills, community } \\
\text { access, psychosocial } \\
\text { support. }\end{array}$ & 452 & & & 1 & 452 & & & 2.3 \\
\hline & subtotal & $\begin{array}{c}452 \\
(35.4 \%)\end{array}$ & & $\begin{array}{c}824 \\
(64.6 \%) \\
\end{array}$ & & 1,2750 & 2.3 & 4.1 & 6.4 \\
\hline $\begin{array}{l}\text { Low } \\
(1.5\end{array}$ & & & $\begin{array}{l}\text { Supported public housing } \\
\text { Supported supervised hostels }\end{array}$ & $\begin{array}{l}864 \\
864\end{array}$ & $\begin{array}{l}1 \\
1\end{array}$ & $\begin{array}{l}864 \\
864\end{array}$ & & & $\begin{array}{l}1.3 \\
1.3\end{array}$ \\
\hline
\end{tabular}




\begin{tabular}{|c|c|c|c|c|c|c|c|c|}
\hline \multirow[t]{3}{*}{ hours)ףף } & $\begin{array}{l}\text { Therapeutic services, } \\
\text { psychosocial support, } \\
\text { Individual advocacy, } \\
\text { Community access, } \\
\text { living skills }\end{array}$ & 4,459 & & 1 & 4,459 & & & 6.7 \\
\hline & subtotal & $\begin{array}{c}4,459 \\
(72.1 \%)\end{array}$ & $\begin{array}{c}1728 \\
(27.9 \%)\end{array}$ & & 6,187 & 6.7 & 2.6 & 9.3 \\
\hline & Grand totals & 5278 & 3878 & & 11,048 & 12.7 & 33.6 & 46.3 \\
\hline
\end{tabular}

Note that totals may not sum exactly, due to rounding

$\dagger$ In calculating the number of patients supported, we assumed that services are targeted at patients with severe and persistent mental illness with complex multi-agency needs (Whiteford, \& Buckingham 2006). We assumed that those receiving Personalised Support will require year on year support. The small number moving out of the group in any one year would be balanced by new inflows.

$\ddagger \quad$ This table cannot be used to derive estimates for the Personalised Support indicative activities separately, as they are not disaggregated for people in Supported Accommodation

$\S$ Support intensity was calculated by reviewing existing program data and creating weighted average hours per week for four levels of program intensity (Edwards et al 2008; Fisher et al 2007; Goodwin, \& Lyons 2001; Meehan et al 2011; NSW Health Department 2006; Seelig et al 2008; Victorian Government Department of Human Services 2008). Calculations are provided in an unpublished report and are available on request from the authors.

$\|$ We assumed that staff worked 38 hours per week for 44 working weeks per year, and that $72 \%$ of staff time was available for direct contact (Personal Communication. Community Mental Health Plan Team, Department of Communities (Disability Services), Queensland Government. September 30, 2009) From patient service hours per FTE, and the number of patient service hours needed per patient place, we were able to calculate required FTEs.

I The Intensive group are patients living in the community who prior to deinstitutionalisation may have resided in long-term facilities. These patients need intensive assistance with daily living activities such as shopping, cooking and maintaining personal hygiene and will require housing to be provided and maintained for them. They may be residing in long-term supported housing intensive programs, 24 hour residential rehabilitation programs, crisis housing and residential respite programs.

t† Patients in the High group may struggle to retain community tenure, being at high risk of becoming homeless or requiring acute psychiatric hospitalisation in the absence of community-based support. These people are residents of $<24$ hour staffed residential rehabilitation programs, and transitional supported housing services. They may include some patients living independently (NSW Health Department 2006; Queensland Health 2008).

执 This is an adjusted count, assuming that $44 \%$ of the home respite service target group is already getting other services included in the taxonomy 
$\S \S$ The sum of the people receiving early intervention, psychosocial support, and home-based respite not tied to housing is 1,764 people. This corresponds to the 1,764 people receiving high support personalised support in Table 2 .

|| || The medium group includes patients who are residents of supported public housing and supervised hostels, as well as people who live independently or with family and carers in private accommodation. They may require assistance with tasks such as living skills, accessing community services and maintaining their community tenure.

ๆף Low group patients require only minimal levels of support, such as a weekly shopping trip, assistance with individual advocacy or recreational outings. They may be living independently or in hostels (Queensland Health 2008). 
Table 4 Group Support Services $† \ddagger$

\begin{tabular}{|c|c|c|c|c|}
\hline Subtype & $\begin{array}{r}\text { Number } \\
\text { of } \\
\text { Patients } \\
\S \\
\end{array}$ & $\begin{array}{r}\text { Total Annual } \\
\text { Patient } \\
\text { Participation } \\
\text { Hours || }\end{array}$ & $\begin{array}{r}\text { Total number of } \\
\text { places per } 100 \mathrm{k} \text { total } \\
\text { pop } \rrbracket \dagger \dagger\end{array}$ &  \\
\hline Clubhouse & 3,314 & 745,741 & 12.26 & 3.07 \\
\hline Structured day programs & 3,314 & 745,741 & 12.26 & 3.07 \\
\hline Drop in centers & 2,762 & 124,290 & 2.04 & 0.31 \\
\hline Community day respite & 1,657 & 99,432 & 1.64 & 0.41 \\
\hline total & 11,048 & $1,715,205$ & 28.20 & 6.85 \\
\hline
\end{tabular}

$\dagger$ Patients accessing Group Support Services predominantly have severe and persistent mental illness (Corrigan et al 2008). We assumed that services are targeted at patients with severe and persistent mental illness with complex multiagency needs (Whiteford, \& Buckingham 2006).

$\ddagger \quad$ Although patients may attend multiple group programs, we assumed that they would have a lead agency, and that service usage among agencies would average out, allowing us to calculate based on lead agency.

$\S$ Number of patients per subtype was derived using estimated proportions of patients attending each subtype (Department of Health and Ageing 2010a).

II This was derived by multiplying number of patients by an estimate of individual patient contact hours per year

I We assumed that services were open 8 hours a day, with 6 hours of patient contact, 5 days per week, making 1380 hours available per year. We assumed a staffing ratio of $1: 4$

†† The number of places required for each service subtype was derived by dividing the number of total patient participation hours by the total available participation hours per place per year, then recalculated as places per 100,000 total population. 
Table 5 Mutual Support \& Self Help (MSSH) † and Community Development $\ddagger \S \|$

\begin{tabular}{|c|c|c|c|}
\hline 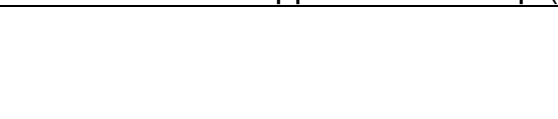 & $\begin{array}{l}\text { National } \\
2007-08 \text { व }\end{array}$ & $\begin{array}{c}\text { Victoria } \\
2008-09+\dagger\end{array}$ & $\begin{array}{l}\text { Queensland } \\
2008-09 \text { 㧊 }\end{array}$ \\
\hline Total budget & $\$ 261 \mathrm{M}$ & $\$ 73 \mathrm{M}$ & $\$ 41.1 \mathrm{M}$ \\
\hline Budget allocated to MSSH & $\$ 4.2 \mathrm{M}$ & $\$ 3.9 \mathrm{M}$ & $\$ 1.7 \mathrm{M}$ \\
\hline Proportion allocated to MSSH & $1.6 \%$ & $5.2 \%$ & $4.1 \%$ \\
\hline $\begin{array}{l}\text { Budget allocated to Community } \\
\text { Development }\end{array}$ & $\$ 6.3 \mathrm{M}$ & -- & $\$ 2.8 \mathrm{M}$ \\
\hline $\begin{array}{l}\text { Proportion allocated to Community } \\
\text { Development }\end{array}$ & $2.4 \% \S \S$ & -- & $6.8 \%$ \\
\hline
\end{tabular}

$\dagger$ MSSH services target patients at all levels of severity, as well as families and carers, who may have multiple contacts with different services providing MSSH (Goldstrom et al 2006). MSSH agencies provide support through a range of individual contacts and group services, which may be of varying duration and intensity. It is difficult to anticipate the exact mix of services, and is therefore difficult to generate planning estimates based on individual's serviced or number of contacts. We therefore chose a proportion of budget allocation as the planning unit.

$\ddagger$ Community Development covers societal scale programs making output units impractical. Planning units were calculated as proportion of budget.

$\S$ We identified the proportion of the mental health community support sector budget spent on MSSH from three sources: Victoria; Queensland; and a national aggregated average of all Australian states. Community Development data was available from Queensland and the national aggregated average.

\| The reported data show considerable variation, which may be due to differences in data collection and reporting across jurisdictions. For example, the national data only counts grants, but does not include block funding, whereas block funding may have been included in the state data. State data may or may not have included spending not able to be classified.

I National aggregated community mental health budget data (Personal communication. Monitoring \& Evaluation Section, Mental Health Reform Branch, Department of Health and Ageing, Commonwealth Government of Australia. November 17, 2009.)

†† Victorian Psychiatric Disability Rehabilitation and Support Services budget data (Personal Communication. Information, Analysis \& Reporting Legislation, Resources \& Analysis Unit Policy, Planning \& Strategy Branch, Mental Health \& Drugs Division Department of Human Services, Government of Victoria .

November 18, 2009.)

㧊 Queensland Disability Services mental health budget data (Personal Communication. Community Mental Health Plan Team, Department of Communities (Disability Services), Queensland Government. September 30, 2009.)

$\S \S$ "Time for Service" (Mental Health Council of Australia 2006), calls for the amount spent nationally on Community Development to be increased to $\$ 10$ million, or $4.7 \%$ of the national budget 